\title{
RESPROUTING AFTER DISTURBANCE: AN EXPERIMENTAL STUDY WITH SHORT-LIVED MONOCARPIC HERBS
}

\author{
Jana Martínková ${ }^{1,2)}$, Jitka Klimešová ${ }^{2)} \&$ Stanislav Mihulka ${ }^{1,3)}$ \\ 1) Faculty of Biological Sciences, University of South Bohemia, Branišovská 31, CZ-370 05 České Budějovice, \\ Czech Republic \\ 2) Institute of Botany, Academy of Sciences of the Czech Republic, Dukelská 135, CZ-379 82 Třebon̆, Czech \\ Republic; fax+420 333 721136, e-mailmartinkova@butbn.cas.cz \\ 3) Institute of Botany, Academy of Sciences of the Czech Republic, CZ-252 43 Prühonice, Czech Republic
}

\begin{abstract}
We experimentally demonstrated the ability of three short-lived monocarpic species to vegetatively regenerate (resprout) from roots after severe disturbance. We assessed the relationship between resprouting ability and (1) timing of injury with respect to life-cycle stage (reproductive vs. vegetative plant), life-history mode (annual vs. winter annual) and phenological stage (flowering vs. fruiting plant), (2) nutrient availability, and (3) disturbance severity (removal of all axillary buds Yes/No).

In a chamber experiment with the annual or potentially winter annual Rorippa palustris, all injured plants resprouted in all nutrient levels and day-length regimes (day-length regimes simulated conditions of an annual and a winter annual cohort). The number of adventitious buds on roots was positively affected only by injury. The extent of regeneration and amount of regenerated biomass were higher at high nutrient level and long-day regime.

In a field experiment with the biennials, Oenothera biennis and Oenothera issleri, both species responded to injuries by resprouting from axillary buds when at least only one axillary bud was still present. However, they were also able to resprout from adventitious buds on roots. Reproductive plants resprouted more frequently at the flowering stage than at the fruiting stage. Resprouting of vegetative plants (rosettes) was equal throughout the year and more frequent than in the reproductive plants.
\end{abstract}

Keywords: Day-length regime, Injury, Nutrient level, Oenothera biennis, Oenothera issleri, Rorippa palustris, Vegetative regeneration

\section{INTRODUCTION}

Disturbance provides areas of bare soil, where competitively less efficient species (i.e., annuals, biennials and short-lived perennials) are able to germinate, grow and survive (HARPER 1977, KLEMOW \& RAYNAL 1983, LÖFGREN et al. 2000, GRIME 2001). However, disturbance is also the most significant factor causing early mortality in these species. Population survival of annual and biennial species depends only on their ability to produce numerous seeds (HARPER 1977, CRAWLEY 1986, VAN DER MEIJDEN et al. 1992, GRIME 2001). Nevertheless, some studies (IRMISCH 1857, WITTROCK 1884, RAUH 1937, KOČVAROVÁ 2002, KLIMEŠOVÁ 2003) suggest a possibility of vegetative regeneration (resprouting) after severe disturbance in some short-lived species. Severe injury to plants may not be fatal in about $2 \%$ of annual species and $14 \%$ of the biennials in Central European flora, because they are able to form de novo adventitious buds on roots (KLIMEŠOVÁ 2003). This ability enables them to rebuild the plant body and complete the reproductive cycle, i.e., to 
produce seeds (DUBARD 1903, RAUH 1937). Regenerated individuals can postpone flowering and fruiting to the next vegetation season, or they do not die after seed production and flower more than once (VAN TOOREN et al. 1987, HAUTEKEETE et al. 2002, KLIMEŠOVÁ 2003).

The presently available information on root sprouting in short-lived monocarpic species is scarce and comes mostly from descriptive and morphological literature (e.g. DUBARD 1903, RAUH 1937, KLIMEŠOVÁ 2003); hence a need to perform manipulative experiments is evident. For this study, we chose the biennial species Oenothera biennis with its already mentioned resprouting ability (DUBARD 1903, RAUH 1937), its relative Oenothera issleri and the annual species Rorippa palustris, both being able to resprout in the field (KLIMEŠOVÁ 2003). The effect of three factors on the resprouting ability was examined.

(1) Timing of injury with respect to life-cycle stage (reproductive vs. vegetative plant), life-history mode (annual vs. winter annual) and phenological stage (flowering vs. fruiting plant). Because, the relative investment into the vegetative vs. reproductive growth varies during the life of a monocarpic plant (e.g. KING \& ROUGHGARDEN 1982, VAN MIERLO \& VAN GROENENDAEL 1991, OLEJNICZAK 2001), we hypothesized that the timing of injury can change the relative investment into vegetative vs. seed reproduction.

(2) Nutrient availability. Nutrient stress may have a similar effect on the growth form of woody species as moderate disturbance (BELLINGHAM \& SPARROW 2000), i.e., nutrient stress stimulates resprouting. Perennial plants experiencing nutrient shortage form more adventitious buds on roots than plants at higher nutrient levels (MC INTYRE \& HUNTER 1975, KLIMEŠ \& KLIMEŠOVÁ 1999). We assumed the same relationship between nutrient availability and the ability to resprout in the short-lived monocarpic species.

(3) Severity of disturbance. Adventitious buds need to differentiate from root cells (ESAU 1965, BURROWS 1990) and they often develop only after injury (PETERSON 1975), whereas axillary buds are formed during normal plant ontogenesis and they are already present on intact plants (ESAU 1965, HARPER 1977). Thus, we assumed that injured plants would "prefer" resprouting from axillary buds than resprouting from adventitious buds on roots.

\section{MATERIAL AND METHODS}

\section{Study species}

Rorippa palustris (L.) BESSER (Brassicaceae) is a cosmopolitan species occurring mostly in naturally or anthropogenically disturbed habitats. This species is an annual, winter annual or short-lived perennial (JÄGER \& WERNER 2002). Its seeds germinate throughout the vegetation season. The early spring cohorts behave as annuals and the late summer cohorts show a winter annual life-history mode (SOSNOVÁ 2003). More than one generation can be produced within one year.

Oenothera biennis L. and Oenothera issleri ROSTAŃSKI (Onagraceae) are non-native species in Europe, which occur mostly in naturally or anthropogenically disturbed habitats. Both species are classically mentioned as being non-clonal, monocarpic and biennial species (HALL et al. 1988, JEHLí́ 1997). Oenothera individuals die immediately after seed production (DIETRICH et al. 1997). Seeds of Oenothera species germinate only during the spring months (BASKIN \& BASKIN 1994). 


\section{Rorippa chamber experiment}

A chamber experiment with plants of Rorippa palustris was performed in the winter of 2001/2002. The plants were grown in two standardized chambers (KLIMABOX ZVK E-008, Váha, Kladno, Czech Republic) for a total of 12 weeks from germination. Irradiance, day and night temperatures and day and night humidities were the same in both chambers (184 $\mu \mathrm{Em}^{-2} \mathrm{~s}^{-1}$; PhAR $62 \mathrm{Wm}^{-2}$, light $-20{ }^{\circ} \mathrm{C}$, dark $-8{ }^{\circ} \mathrm{C}$; light $-70 \%$ humidity, dark $-90 \%$ humidity). Treatments consisted of two day-length regimes: LONG DAY $=15 \mathrm{~h}$ light $/ 9 \mathrm{~h}$ dark, SHORT DAY $=9 \mathrm{~h}$ light/15 h dark; and two nutrient levels: HIGH NPK 0.21/0.1/0.15 [g/kg of substrate]; LOW NPK 0.05/0.025/0.03 [g/kg of substrate]. The long-day treatment induced an annual life-history mode and the short-day treatment created a winter annual life-history mode in the experimental plants. Low and high nutrient levels simulated nutrient shortage and normal nutrient conditions, respectively. Thirty replicates (one replicate $=$ one plant in a pot) were used for each combination of treatments.

After eight weeks from germination, 15 plants exposed to each combination of treatments were injured at the rosette stage. All aboveground biomass was removed along with the root crown, i.e., all axillary buds were destroyed. As only the roots were left in place, resprouting was possible only from adventitious buds on the roots.

Growth characteristics such as number of leaves, rosette diameter and the amount of removed biomass were recorded at the time of injury. The number of regenerated individuals, number of adventitious buds on roots, root and shoot biomass, number of leaves and rosette diameter were recorded four weeks after injury. Two growth characteristics were calculated root/shoot ratio (for injured individuals shoot biomass was calculated as the sum of removed and regenerated biomass) and the extent of regeneration (ratio of regenerated/removed biomass).

\section{Oenothera field experiment}

An experiment with natural populations of Oenothera biennis and Oenothera issleri was performed in the summer of 2001 at the railway station near České Budějovice, Czech Republic $\left(49^{\circ} 3^{\prime} \mathrm{N}, 14^{\circ} 22^{\prime} \mathrm{E}\right)$.

Treatments consisted of two types of experimental injury:

(i) cutting of plants $5 \mathrm{~cm}$ above the root crown + defoliation (some axillary buds left in place)

(ii) cutting of plants $1 \mathrm{~cm}$ below root crown (all axillary buds were removed, only roots left in place).

Those treatments were applied at two life-cycle stages of the species - to vegetative rosettes and reproductive plants, respectively, and at two different phenological phases (in June and August) - to both younger and older vegetative rosettes, and to flowering and fruiting plants.

Ten replicates were used for all treatments and both species. The diameter of rosettes, number of leaves and removed biomass were recorded for the rosettes (vegetative plants) at the time of their injury. Similarly, the length of stem, basal stem diameter, number of fruits or flowers and biomass were recorded for the reproductive plants. The type of regeneration 

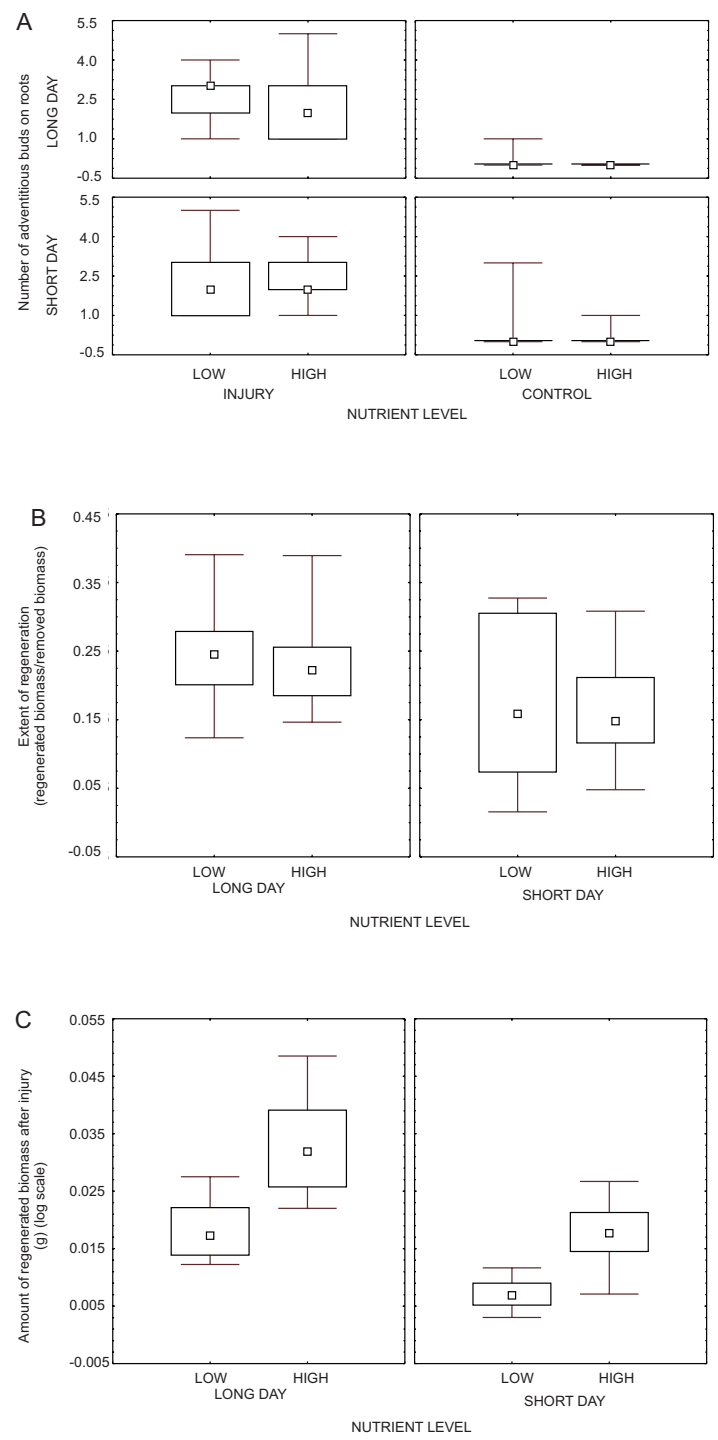

Fig. 2. Characteristics of resprouting in the chamber experiment with Rorippa palustris. A - number of adventitious buds on roots formed after injury; B - extent of regeneration expressed as a ratio of regenerated/removed biomass; $\mathrm{C}$ - amount of regenerated above-ground biomass after injury. CONTROL refers to individuals without injury. Low and high refer to nutrient levels. Median, quartiles and ranges are shown. For significance levels, Wald statistics, $n$ and d.f. see Table 1 . (from adventitious buds on roots or axillary buds on stems) and the number of regenerated individuals were evaluated four weeks after experimental injury.

\section{Statistical analysis}

All statistical analyses were done using the STATISTICA 5.5 package. Logarithmic transformation of the characteristics (biomass amounts and calculated ratios) was used. The Rorippa chamber experiment was evaluated by main effects 3-way ANOVA (effect of light regime, nutrient level and injury), 2-way ANOVA (effect of light regime and nutrient level) and simple regression in generalized linear models (Poisson or gamma distribution, log link function). Main effects 4-way ANOVA (effect of species, phenological stage, life-cycle stage and type of injury) and general customs design in generalized linear models (binomial distribution, logit link function) were used for evaluation of the Oenothera field experiment.

\section{RESULTS}

\section{Rorippa chamber experiment}

After two weeks, all injured individuals of Rorippa palustris resprouted from adventitious buds on roots in all experimental treatments of the chamber experiment (Fig. 1A, p. 11), even though the variability in the initial plant size was substantial at the time of injury. The number of new adventitious buds on roots was not related to initial plant size (rosette 
Table 1. Significance level and Wald statistics for all tested factors and measured characteristics in Rorippa chamber experiment. $\left({ }^{* *}\right) P<0.001,(* *) P<0.01,\left({ }^{*}\right) P<0.05$, n.s. $=$ non-significant. $D . f .=1$ for each test. Number of observations is 120 , or 60 - in the case where effect of injury was not tested.

\begin{tabular}{llcc} 
Measured characteristics & Factor & Wald statistic & $P$-level \\
\hline Rosette diameter at the time of injury & Injury & - & - \\
& Nutrient level & 93.53 & $* * *$ \\
& Day-length regime & 28.34 & $* * *$ \\
Number of leaves at the time of injury & Injury & - & - \\
& Nutrient level & 10.539 & $* *$ \\
Number of adventitious buds on roots & Day-length regime & 0.194 & n.s. \\
& Injury & 61.041 & $* * *$ \\
& Nutrient level & 0.799 & n.s. \\
& Day-length regime & 0.0662 & n.s. \\
Regenerated biomass & Injury & - & - \\
& Nutrient level & 84.380 & $* * *$ \\
Extent of regeneration & Day-length regime & 98.433 & $* * *$ \\
(regenerated/removed above-ground biomass) & Injury & - & - \\
& Nutrient level & 0.755 & n.s. \\
Rosette diameter after regeneration & Day-length regime & 8.554 & $* *$ \\
& Injury & 7.483 & $* *$ \\
& Nutrient level & 63.535 & $* * *$ \\
Number of leaves after regeneration & Day-length regime & 62.357 & $* * *$ \\
& Injury & 138.021 & $* * *$ \\
Root biomass & Nutrient level & 24.665 & $* * *$ \\
& Day-length regime & 5.613 & $*$ \\
& Injury & 194.39 & $* * *$ \\
& Nutrient level & 106.14 & $* * *$ \\
& Day-length regime & 60.00 & $* * *$ \\
& Injury & 15.950 & $* * *$ \\
& Nutrient level & 2.551 & n.s. \\
& Day-length regime & 19.054 & $* * *$ \\
\hline
\end{tabular}

diameter: Wald statistic $=0.12$, d.f. $=1, n=120, P>0.05$; number of leaves: Wald statistic $=$ 0.262 , d.f. $=1, n=120, P>0.05$ ). The number of new adventitious buds on roots was significantly affected only by injury (Wald statistic $=61.041$, d.f. $=1, n=120, P<0.001$ ), even though some adventitious buds on roots were also formed in the control treatment. The day-length regime and nutrient level did not significantly affect the formation of adventitious buds (Fig. 2, Table 1). The amount of regenerated biomass was significantly affected by the day-length regime (Wald statistics $=98.43$, d.f. $=1, n=60, P<0.001$ ) and also by nutrient level (Wald statistics $=84.38$, d.f. $=1, n=60, P<0.001$ ). The amount of regenerated biomass was higher at the higher nutrient level and in the long-day light regime (Fig. 2, Table 1). Nevertheless, the extent of regeneration expressed as the ratio of regenerated/removed biomass was significantly affected only by the day-length regime (Wald statistic $=8.554$, d.f. $=1, n=60, P<0.01$ ) (Fig. 2, Table 1). Rosette diameter and number of leaves were significantly affected by all factors (Table 1), but the reaction of these characteristics was different. Injury positively influenced rosette diameter and negatively affected the number of 


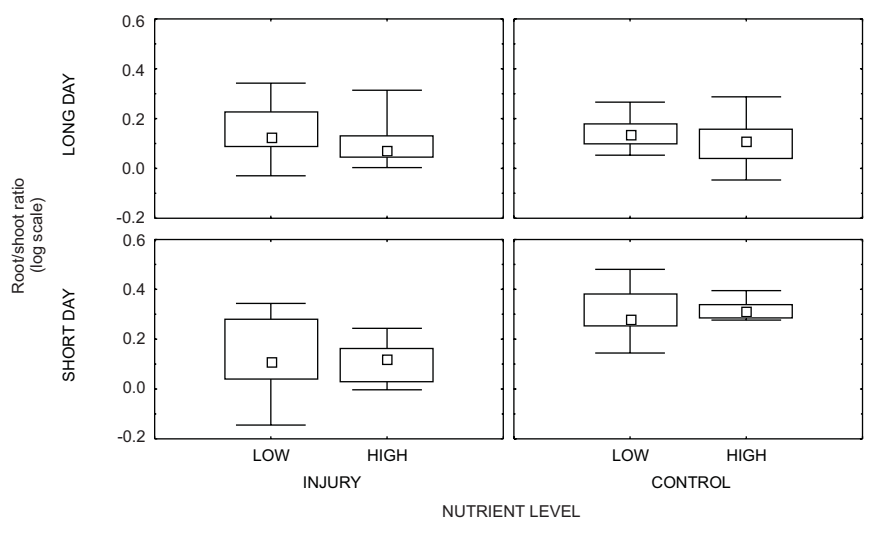

Fig. 3. Effects of injury, nutrient level and day-length regime on root/shoot ratio in Rorippa chamber experiment. CONTROL refers to individuals without injury. Low and high refer to nutrient levels. Mean, quartiles and Table 1. range are shown. For significance levels, Wald statistics, $n$ and d.f. see

leaves. The amount of root biomass was also affected by all tested characteristics (Table 1). Injury, low nutrient level and short day-length regime reduced the amount of root biomass. Root/shoot ratio was significantly lower in the injury treatment than in the control and also in the long day-length regime, while nutrient level did not influence this characteristic (Table 1, Fig. 3). Rosette diameter measured at the time of injury was significantly affected by the nutrient level and day-length regime, but the number of leaves measured at the time of injury was affected only by the nutrient level, whereas the impact of day-length regime was non-significant (Table 1).

\section{Oenothera field experiment}

Both species Oenothera biennis and $O$. issleri were able to resprout after injury from both axillary buds on stems and adventitious buds on roots equally (Fig. $1-$ p. 11, Fig. $5-$ p. 12) (Wald statistic $=1.68$, d.f. $=1, n=160, P>0.05$ ).

Vegetative and reproductive plants of both species regenerated more frequently in treatments where the root crown was left in place (Wald statistic $=11.03$, d.f. $=1, n=160, P<$ 0.001 ) (Fig. 4). When the aboveground biomass of vegetative plants (rosettes) was removed and their root crown left in place, all injured individuals regenerated (Fig. 4). All these individuals regenerated only from axillary buds. On the contrary, not all treated reproductive plants resprouted (Fig. 4). The ability to resprout from adventitious buds on roots (treatment where all axillary buds were removed) was found in both injured vegetative and reproductive plants, but injured vegetative plants resprouted significantly more frequently (Wald statistic $=$ 22.26, d.f. $=1, n=80, P<0.001)$.

The number of regenerated individuals was affected by the time of injury only in reproductive plants (Wald statistic $=5.53$, d.f. $=1, n=80, P<0.05$ ) and only the time of injury could be used as a predictor of resprouting probability (Wald statistic $=5.88$, d.f. $=1, n=80, P$ $<0.05$ ). The ability to regenerate was lower in August (fruiting plants) than in June (flowering plants). Vegetative plants (rosettes) were not significantly affected by the time of injury.

No relationship was found between the resprouting ability and measured characteristics at the time of injury (number of rosette leaves, number of fruits and length of stems, etc.). 

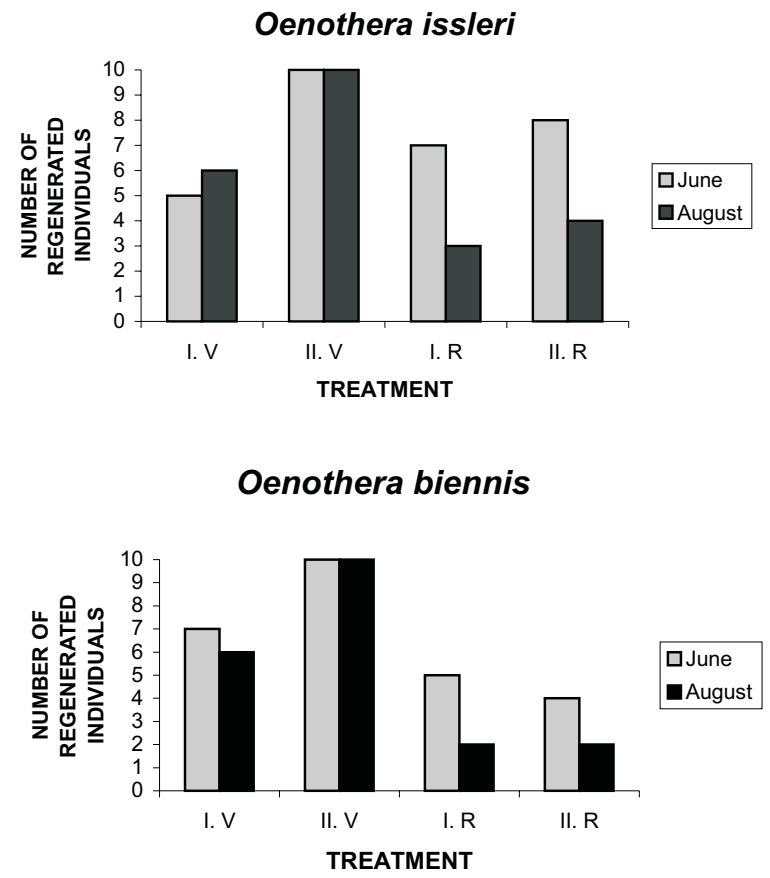

Fig. 4. Regenerated individuals for different injury treatments in a field experiment with Oenothera species. V-vegetative plants; R-reproductive plants; I. - removal of above-ground biomass together with the root crown; II. - removal of aboveground biomass of vegetative plants, with the root crown left in place.

\section{DISCUSSION}

We found that the studied short-lived monocarpic species are able to cope with severe disturbance by resprouting from their roots (Figs. 1, 5). Thus, we confirm the historical studies of IRMISCH (1857), DUBARD (1903), RAUH (1937) etc., who described adventitious root sprouting in short-lived monocarpic species for the first time. Our results also suggest that the timing and severity of injury influence the extent of this ability, while the nutrient level have less important effect on resprouting in the studied species.

\section{Timing of injury}

Experimental conditions (short vs. long day) influenced the growth of Rorippa palustris. Plants in the short-day treatment had prostrate rosettes with the apical meristem pushed into the ground, whereas plants cultivated in the long-day treatment had rosettes with erect leaves and aboveground apical meristem (Fig. 1). The geophyllous growth form of plants in the short-day treatment corresponded with our observations that plants germinating under late summer conditions behave as winter annuals. This fact was supported also by higher $\mathrm{R} / \mathrm{S}$ ratio in plants cultivated in the short-day treatment, because this allocation is advantageous in spring regrowth (HIROSE \& KACHI 1982, VOLENEC et al. 1991, BUSHWAY \& PRITTS 2002). Despite these growth differences, the resprouting ability was independent of the life-history mode of experimental plants; injury was the most important factor causing an increase in the number of root buds in Rorippa palustris. The difference between plants of the same life-history mode was found only in the extent of regeneration (regenerated/removed biomass).

Plants cultivated under long-day conditions causing the annual life-history mode had more root biomass than winter annuals in our experiment, despite their lower $\mathrm{R} / \mathrm{S}$ ratio. Higher root biomass may have caused more vigorous resprouting in annual plants than in winter annual plants. Aboveground biomass was probably also enhanced by more intensive compensatory photosynthesis in the long-day treatment (MEYER 1998). It seems that injury to the plant body 
is more risky for plants in the winter annual life-history mode that for plant in the annual life-history mode.

The life-cycle stage and phenological stage of the treated Oenothera species had an important effect on their resprouting ability. Both vegetative and reproductive plants of Oenothera species were able to regenerate; nevertheless, vegetative plants resprouted more frequently than reproductive plants. This is in contradiction with the findings of DUBARD (1903) and RAUH (1937), who reported successful resprouting of Oenothera biennis only in the rosette stage and of the biennials Alliaria officinalis and Bryonia dioica only at the end of the first growing season. This pattern of resprouting ability throughout the life of monocarpic species can be interpreted as a consequence of accumulation of reserve assimilates during the vegetative phase and of their depletion during the reproductive phase of the life cycle (DUBARD 1903, CHAPIN et al. 1990). Nevertheless, this allocation cannot be seen as a single switch of investment into vegetative and reproductive growth, but we can rather expect graded allocation as it was proposed earlier in trade-off models of monocarpic plants (KING \& ROUGHGARDEN 1982, KUDOH et al. 2002).

\section{Nutrient availability}

Nutrient level did not significantly affect the number of adventitious buds in our experiment. Plants at low nutrient level showed only a slight tendency to produce more adventitious buds on their roots than did plants at high nutrient level. These results were probably caused by the short duration of our experiment ( 8 weeks), because in another longer experiment (6 months) with Rorippa palustris, we found a significantly higher number of root buds in the nutrient stress treatment (MARTíNKOVÁ et al., in press).

\section{Severity of disturbance}

As we expected, both Oenothera species definitely preferred resprouting from axillary buds, when at least only one axillary bud was still present. The growth of adventitious shoots from buds on roots was probably more energy demanding and resprouting from roots required a longer time. Alternatively, the presence of axillary buds could prevent adventitious root-sprouting in Oenothera species, because correlative inhibition of root buds can be broken by removal of the present leaves and apical or axillary buds (HORVATH 1998, 1999).

Disturbance to plant body is a crucial event that may considerably influence the plant's future. In the case of short-lived monocarpic species with the ability to resprout from roots, the effect of disturbance is serious but not lethal. Even though the ability is influenced by many factors (e.g. nutrient level, timing of injury), root-sprouting species are still favoured over injured species without this ability. Species forming a bud bank on roots are able to compensate for the loss of all aboveground biomass by vegetative regeneration, and do not only rely on regeneration from seeds. Consequently, population extinction in root-sprouting species may be less probable than in other populations due to a higher survival of individuals with ability of root-sprouting.

Acknowledgement: This research was supported by the grants no. 206/01/1039 and 206/03/H034 of the Grant Agency of the Czech Republic, and AV0Z6005908 by the Faculty of Biological Sciences, University of South 
Bohemia, České Budějovice, Czech Republic. We would like to express our thanks to Phyllis Quinn for improving our English, Harry H. van de Steeg for translation of a Dutch paper, Jan Květ and three anonymous reviewers for valuable comments on the manuscript.

\section{REFERENCES}

BASKIN C.C. \& BASKIN J.M. (1994): Germination requirements of Oenothera biennis seeds during burial under natural seasonal temperature cycles. Canad. J. Bot. 72: 779-782.

BELLINGHAM P.J. \& SPARROW A.D. (2000): Resprouting as a life history strategy in woody plant communities. Oikos 98: 409-416.

BURROWs G.E. (1990): Anatomical aspects of root bud development in hoop pine (Araucaria cunninghamii). Austral. J. Bot. 38: 73-78.

BUSHWAY L.J. \& PRITTS M.P. (2002): Enhancing early spring microclimate to increase carbon resources and productivity in June-bearing strawberry. J. Amer. Soc. Hort. Sci. 127: 415-422.

ChAPIN S.F. III, SCHUlzE E.-D. \& MOONEY H.A. (1990): The ecology and economics of storage in plants. Annual Rev. Ecol. Syst. 21: 423-447.

CRAWLEY M.J. (1986): Plant ecology. Blackwell, Oxford.

DiETRICH W., WAGNER W.L. \& RAVEN P.H. (1997): Systematics of Oenothera section Oenothera subsection Oenothera (Onagraceae). Syst. Bot. Monogr. 50: 1-234.

DuBARD M. (1903): Recherches sur les plantes a bourgeons radicaux. Ann. Sci. Nat., Bot. 17: 109-225.

ESAU K. (1965): Plant anatomy. Wiley Eastern Limited, New Delhi.

GRIME J.P. (2001): Plant strategies, vegetation processes, and ecosystem properties. John Wiley \& Sons, Chichester.

Hall I.V., Steiner E., ThreAdgill P. \& JONES R.W. (1988): The biology of Canadian weeds. 84. Oenothera biennis L. Canad. J. Pl. Sci. 68: 163-173.

HARPER J.L. (1977): Population biology of plants. Academic Press, London.

HAUTEKEETE N.-C., PIQUOT Y. \& VAN DIJK K. (2002): Life span in Beta vulgaris ssp. maritima: the effects of age at the first reproduction and disturbance. J. Ecol. 90: 508-516.

HIROSE T. \& KACHI N. (1982): Critical plant size for flowering in biennials with special reference to their distribution in a sand dune system. Oecologia 55: 281-284.

HORVATH D.P. (1998): The role of specific plant organs and polar auxin transport in correlative inhibition of leafy spurge (Euphorbia esula) root buds. Canad. J. Bot. 76: 1227-1231.

HORVATH D.P. (1999): Role of mature leaves in inhibition of root bud growth in Euphorbia esula L. Weed Sci. 47: 544-550.

IRMISCH T. (1857): Ueber die Keimung und die Erneurungsweise von Convolvulus sepium und C. arvensis, so wie über hypokotylische Adventivknospen bei krautigen phanerogamen Pflanzen. Bot. Zeitung 15/28: 465-474, 489-497.

JÄGER E.J. \& WERNER K. (2002): Excursion Flora von Deutschland, Band 4., Gefäßpflanzen: Kritischer Band. Ed. 9. Spektrum Akademischer Verlag Heidelberg, Berlin.

JeHLíK V. (1997): 2. Oenothera L. In: SLAVíK B. (ed.), Květena České Republiky 5 (Flora of the Czech Republic 5), Academia, Praha, pp. 68-94.

KING D. \& ROUGHGARDEN J. (1982): Graded allocation between vegetative and reproductive growth for annual plants in growing season with random length. Theor. Populat. Biol. 22: 1-16.

KLEMOW K.M. \& RAYNAL D.J. (1983): Population biology of an annual plant in a temporally variable habitat. $J$. Ecol. 71: 691-703.

KLIMEŠ L. \& KLIMEŠOVÁ J. (1999): Root sprouting in Rumex acetosella under different nutrient levels. Pl. Ecol. 141: 33-39.

KLIMEŠOVÁ J. (2003): Monokarpické rostliny schopné přežít silnou disturbanci (Monocarpic plants surviving severe disturbance). Zprávy Čes. Bot. Společn., Mater [in press].

KoČVAROVÁ M. (2002): Životni cyklus druhu Rorippa palustris a jeho význam pro výskyt na sekundárních stanovištich (Life history of Rorippa palustris in disturbed habitats). MSc. Thesis. Faculty of Biological Sciences, University of South Bohemia, České Budějovice. 
KUDOH H., KACHI N., KAWANO S. \& ISHIGURIS Y. (2002): Intrinsic cost of delayed flowering in annual plants: negative correlation between flowering time and reproductive effort. Pl. Spec. Biol. 17: 101-107.

LÖFGREN P., ERIKSSON O. \& LEHTILÄ K. (2000): Population dynamics and the effect of disturbance in the monocarpic herb Carlina vulgaris (Asteraceae). Ann. Bot. Fenn. 37: 183-192.

MARTínKOVÁ J., KoČVAROVÁ M. \& KLIMEŠOVÁ J. (2004): Resprouting after disturbance in the short-lived herb Rorippa palustris (Brassicaceae): an experiment with juveniles. Acta Oecol. (in press).

MC INTYRE G.L \& HUNTER J.H. (1975): Some effects of the nitrogen supply on growth and development of Cirsium arvense. Canad. J. Bot. 53: 3012-3021.

MEYER G.A. (1998): Mechanisms promoting recovery from defoliation in goldenrod (Solidago altissima). Canad. J. Bot. 76: 450-459.

OLEJNICZAK P. (2001): Evolutionary stable allocation to vegetative and sexual reproduction in plants. Oikos 95: $156-160$.

PETERSON R.L. (1975): The initiation and development of root buds. In: TORREY J.G. \& CLARKSON D.T. (eds.), The development and function of roots, Academic Press, London, pp. 125-161.

RAUH W. (1937): Die Bildung von Hypocotyl- und Wurzelsprossen und ihre Bedeutung für die Wuchsformen der Pflanzen. Nova Acta Leop. 4/24: 395-553.

SOSNOVÁ M. (2003): Vegetativní regenerace druhu Rorippa palustris (L.) BESSER (Vegetative regeneration in Rorippa palustris (L.) BESSER). Bc. Thesis, Faculty of Biological Sciences, University of South Bohemia, České Budějovice.

VAN DER MeIJDEn E., KlinKhamer P.G.L., DE JONG T.J. \& VAN WiJK C.A.M. (1992): Meta-population dynamics of biennial plants: how to exploit temporary habitats. Acta Bot. Neerl. 41: 249-270.

VAN MieRLO J.E.M. \& VAN GROENENDAEL J.M. (1991): A population dynamics approach to the control of Anthriscus sylvetris (L.) HOFFM. J. Appl. Ecol. 28: 128-139.

VAN TOOREN B.F., BIK L. \& BOBBINK R. (1987): Hoe reageert Krijtgentiaan (Gentianella germanica) op het vervroegd maaien van de kalkgraslanden? (How does Gentianella germanica react on mowing of chalk grasslands earlier in the season?) Natuurhist. Maandbl. 76: 55-59.

VoleneC J.J., BoyCe P.J. \& Hendershot K.L. (1991): Carbohydrate-metabolism in taproots of Medicago sativa L. during winter adaptation and spring regrowth. Pl. Physiol. 96: 786-793.

WitTROCK V.B. (1884): Ueber Wurzelsprossen bei krautigen Gewächsen, mit besonderer Rücksicht auf ihre verschiedene biologische Bedeutung. Bot. Centralbl. 17(8,9): 227-232, 257-264.

Received 5 August 2002, revision received 23 May 2003, last revision received and accepted 21 October 2003

Encl. Fig. 1 - p. 11 , Fig. 5 - p. 12 


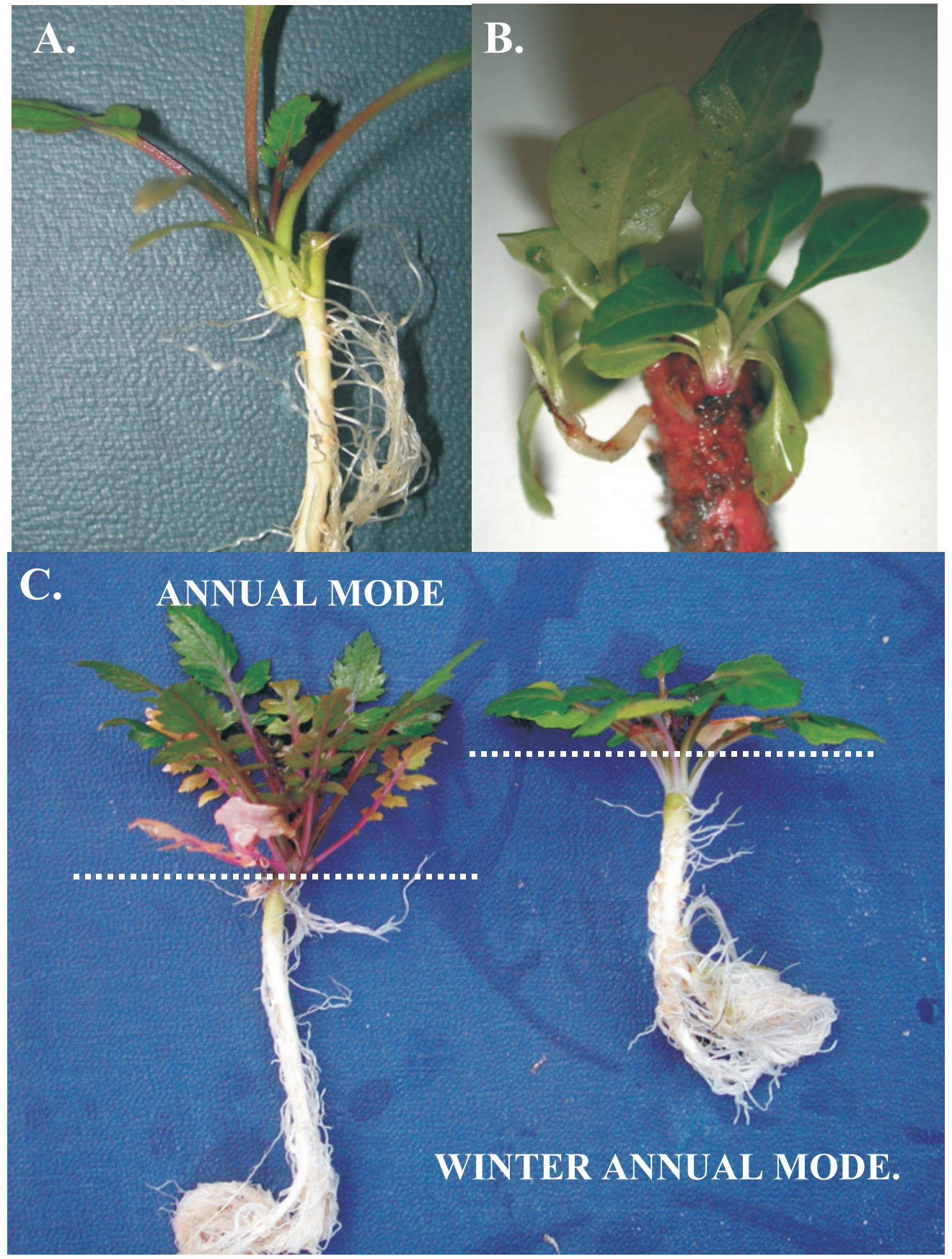

Fig. 1. Vegetative regeneration (resprouting) from adventitious buds on roots after experimental injury in Rorippa palustris (A) and Oenothera issleri (B). Different growth forms of non-injured plants of Rorippa palustris in annual and winter annual life-history mode $(\mathrm{C})$ - ground level is shown. 


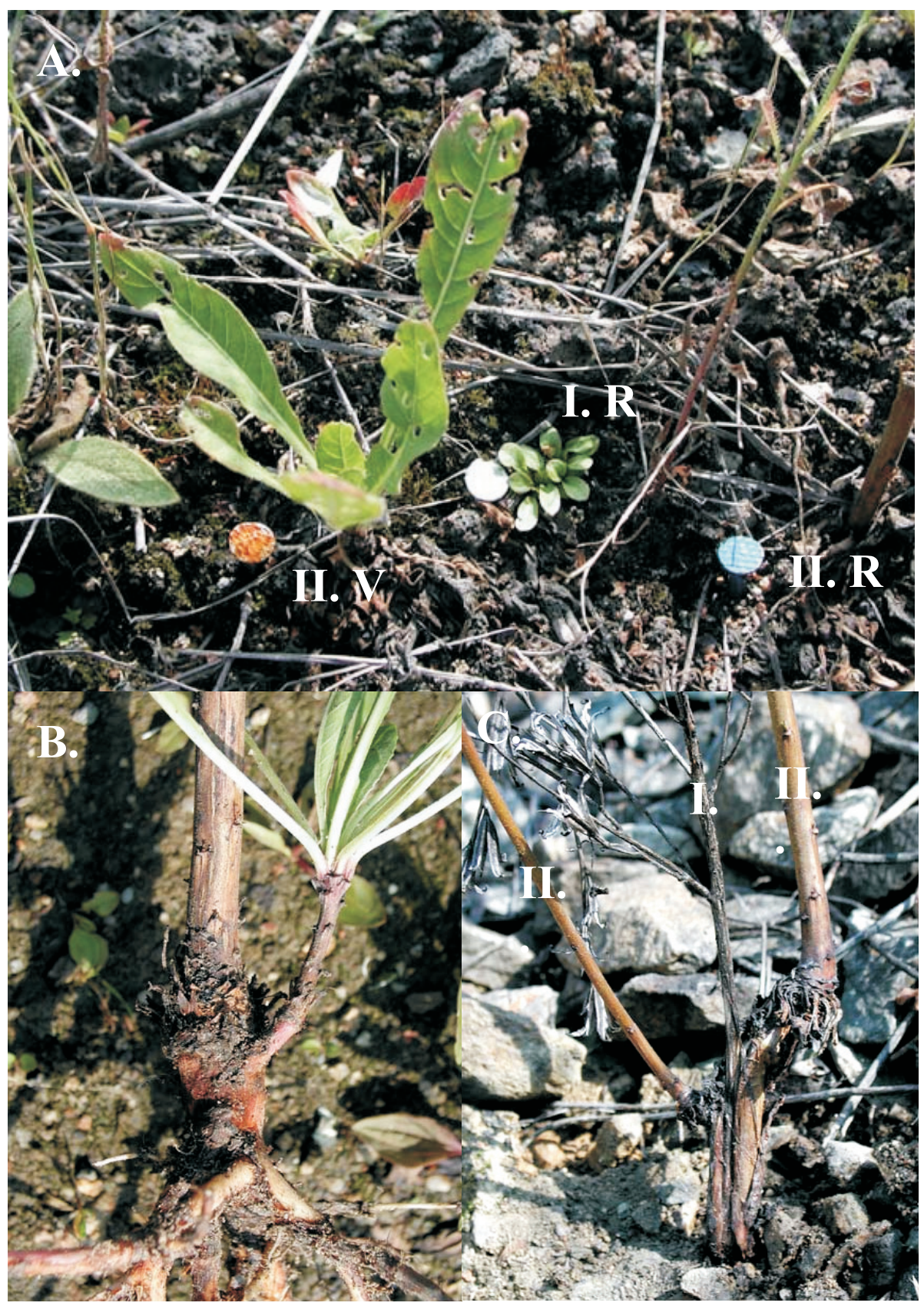

Fig. 5. A. Oenothera issleri individuals in different injury treatment of a field experiment. II.V - Removal of aboveground biomass of rosette without root crown (successful regeneration), I.R - removal of aboveground biomass of generative stem together with root crown (successful regeneration) II.R - removal of aboveground biomass of generative stem without root crown (regeneration fails) B. Oenothera issleri - spontaneous resprouting from adventitious buds on roots, plant was found in the field. C. Oenothera biennis - polycarpic individuum: I. - current year generative stem, II. - previous year generative stem, plant was found in the field. 